\title{
DIE BETEKENIS EN PLEK VAN DIE HERMENEUTIEK
}

deur

\author{
J. H. KOEKEMOER
}

\section{Inleiding :}

Die woord hermeneutiek gaan terug op die woord „ERMENEUEIN" wat ook in die Nuwe Testament voorkom. Ons kom die woord teë in die sin van "oorbring in 'n ander taal", (vertaal) - maar ook in die sin van ,uitlê" en „vertolk":

„Hermeneutiek is dus die wetenskap waarin gehandel word oor die beginsels, metodes en hulpmiddels vir die uitlê van 'n geskrif". ') Hieronder kan dan verstaan word enige geskrif van enige wetenskap. En elke wetenskap stel sy eie eise vir die verstaan van sy geskrifte. Die Bybelse Hermeneutiek verskil egter in 'n sekere sin hiervan. Dit het naamlik te doen met die Heilige Skrif as Woord van God. Daarom sal die reëls wat hier geld in die Skrif self gesoek moet word. En wie in die Hermeneutiek besig is met die reëls vir die uitlê van die Skrif het die begeerte om weerstand te bied teen enige willekeur, wat ondanks die erkenning van die•Skrif as die Woord van God, aan sy konkrete gesag verbygaan.

Voordat daar nou oor die betekenis van die Bybelse Hermeneutiek gehandel sal word, dink ek dat dit goed sal wees as ons eers sy ensiklopediese plek in die vakgebied van die Teologie sal bepaal.

Wanneer ons dit wil doen, kom ons voor die probleem te staan dat die woorde Hermeneutiek en Eksegese eintlik dieselfde beteken. Hulle het naamlik albei met die uitleg van die Skrif te doen. Ons kan egter die onderskeiding maak en sê dat Eksegese die praktiese doenigheid van die uitleg van die Skrif is, terwyl Hermeneutiek nie eksegese van die Skrif nie, maar besinning oor die geskiedenis, beginsels, aard en verhouding van die eksegese tot die res van die Teologiese vakke is. Die doenigheid van die Eksegese is dus eintlik die objek van die Hermeneutiek. 'n Mens kan ook sê die Hermeneutiek is 'n hulpmiddel vir die Eksegese. Die Bybelse Hermeneutiek hou sig besig met die probleme insake die interpretasie van die $\mathrm{Ou}$ en die Nuwe Testamente" ${ }^{2}$ )

1) Encyclopedie van het Christendom, Protestantse deel, bls. 410.

2) Encyclopedie van het Christendom, bls. 410. 


\section{Die plek van die Eksegese en eventueel ook die plek van die Hermeneutiek.}

Hier is ons uitgangspunt die Reformatoriese stelling van "Sola Scriptura". By die Reformasie is "die tese van die alleengeldigheid van die Skrif 'n aksioma". "). Die Heilige Skrif is die ,enigste bron en norm waarop ons ons geloof bou, waarna ons dit reël en waarmee ons dit bevestig". $\left.{ }^{+}\right)$In die Reformatoriese Teologie neem die Heilige Skrif altyd die sentrale plek in. Formeel kan dus gestel word dat die uitleg van die Skrif vir die Reformasie ook na aan die middelpunt sal staan. Hieroor kan daar 'n enorme hoeveelheid vrae opduik, soos byvoorbeeld: Watter Skrif? Watter uitleg? Is dit die uitleg deur die individu of deur die kerk? Belangrik is egter dat as die eksegese sentraal wil wees omdat die Skrif sentraal is, dit uiters noodsaaklik is dat die eksegese reg sal wees. Om hierdie rede sal die plek van die $f^{2}$ rmeneutiek ook hier wees, want hy bemoei hom juis daarmee dat die eksegese reg en suiwer sal wees. Die Hermeneutiek is dus aan die eksegese gekoppel en ,,sy wese en taak sal saamhang en bepaal word deur die wese en taak van die eksegese". ${ }^{5}$ ) By die uitlê van elke Skrifgedeelte sal die hermeneutiese vrae wat van toepassing is, elke keer weer opnuut gevra moet word.

\section{Vasstelling van die probleemveld.}

Die bedoeling van die eksegese is altyd om die Skrif uit te lê. Wanneer die eksegese so sê ontstaan die vraag: Watter Skrif? En as jy sê watter Skrif kom daaruit weer twee probleme na vore.

1. Die omvang van die Skrif d.w.s. die kwessie van die Kanon.

Onthou egter dat die Hermeneutiek nie Kanongeskiedenis of Kanoniek is nie. Hy leen alleen sekere gegewens by die Kanongeskiedenis en die Kanoniek wat vir hom as wetenskap van uitleg diensbaar is.

2. Watter teks van die Skrif.

,Die Hermeneutiek wil oor die uitleg handel. Maar om die swetenskap van die uitleg te dien leen hy by die teksgeskiedenis en tekskritiek sekere bruikbare gegewens. Nadat die

3) Otto Weber - Grundlagen der Dogmatik - erster Bạnd - Neukirchen Moers. bls. 25.

1) Ned. Geloof sbelydenis artikel 5 .

5) Dr. S. Greijdanus Schriftbeginselen ter Schriftverklaring. J. H. Kok. Kampen, 1946, bls. 7. 
Hermeneutiek dan verneem het watter boeke tot die Heilige Skrif behoort en watter teks en teksgroepe daartoe behoort en met watter tegnieke die teks vasgestel is, kan hy die volgende vrae vra:

1. Hy kan vra na die draagkrag van die begrip Kanon en van die werkwyse van teksvasstelling en tekskritiek vir die wetenskap van die uitleg waaroor hy handel en

2. hy kan nagaan watter beginsels agter die werkwyse van die Kanoniek lê.

As hy dit vasgestel het, kan hy weer verder vra of die Skrif dan wel uitleg nodig het. Want as die Skrif vanself so duidelik is dat hy geen uitleg nodig het nie, dan is die eksegese nie nodig nie.

Die vraag is egter of die perspicuitas van die Skrif werklik bedoel dat die Skrif in sigself so duidelik is dat hy geen uitleg nodig het nie. Is daar nie wel dele var ie Skrif wat onduidelik is nie? Byvoorbeeld die geskiedenis van die seuns van God en die dogters van die mense en die ontstaan van die reuse in Gen. 6.

Moet die perspicuitas van die Skrif nie so verstaan word dat die onduidelikheid van die Skrif eers na moeisame werksaamheid deur die Skrif self verklaar word nie.

'n Mens kan natuurlik vra hoekom dit so is dat daar in die Skrif onduidelikhede is. Die antwoord kan hierin opgesluit lê: Die Skrif het oor duisende jare ontstaan en elke keer die taal van sy tyd gepraat, wat nie weer die taal van elke latere tyd van die Bybel self was nie en ook nie die taal van ons tyd is nie. In die uitlê van die Skrif sal dus altyd ' $n$ bepaalde afstand oorbrug word.

Vergelyk die verhaal van die Emmausgangers in Lukas 24 waar Christus self van Moses en al die profete af begin het en vir hulle uitgelê het in al die Skrifte die dinge wat op Hom betrekking het.

Ons kry hier waar die Skrif die taal van sy tyd praat wat nie die taal van ons tyd is nie, te doen met die probleem van inhoud en vorm. Ons kan vra of die Reform toriese perspicuitas nie beteken dat die inhoud altyd duidelik is nie, maar nie die vorm waarin dit gebring word nie. Want die vraag is hoe moet ons die verkondiging van die taal van daardie tyd oorbring na die taal van ons tyd dat dit reg cn verstaanbaar is. 
Ons sny hier twee probleme aan.

1. Die probleem van die Entmythologisierung.

Bultman beweer dat die vorm mitiese beeldspraak is waarin 'n idee gehuisves is wat ons 'n moderne pak klere moet aantrek.

'n Mens kan teenoor Bultman vra of die waarheid van die Bybel en in hoeverre die waarheid van die Bybel slegs idee is. Of en in hoeverre daardie beeldspraak mitologie is.

Hier is met ander woorde die vraag van in hoeverre vorm en inhoud van mekaar onderskei of geskei kan word aan die orde. Bultman meen hulle kan volkome van mekaar geskei word.

Die vraag is egter of hulle so maklik van mekaar geskei kan word. Is vorm nie ook van betekenis vir die verstaan van die inhoud nie? Het die tydgebondenheid in die Skrifgebruik nie betrekking op vorm en inhoud nie? En die blywend gesaghebbende in die Skrifgebruik, betref dit behalwe die inhoud nie rook die vorm nie ? Sal daar nie na ander kategorieë gesoek moet word om die hermeneutiese crux aangaande die verhouding aan die tydgebondene en die blywende in die toepassing van die Bybel op te klaar nie?

2. Die probleem van die bedoeling van die eksegese. Die bedoeling van die eksegese is naamlik dit:

(i) Wat geskryf staan soos dit daar geskryf staan.

(ii) Om uit wat daar nou geskryf staan, die oorspronklike woord wat gesê is agter te kom.

Hieruit spruit dan die hermeneutiese vraag van die verhouding van die Ou Testament tot die Nuwe Testament.

In die Nuwe Testament vind ons ook tipes van eksegese waar die Nuwe Testament die Ou Testament uitlê. Byvoorbeeld in Galate 4 waar Paulus die geskiedenis van Hagar, Ismael, Sara en Isak op 'n sekere manier uitlê. Die vraag is nou of hierdie manier van uitleg op die een plek die enigste outoritatiewe manier van uitleg ook van ander Skrifgedeeltes is ?

Nou vind mens egter dat Paulus op ander plekke ander maniere van uitleg gee, byvoorbeeld in Galate $3: 16$, „Nou is aan Abraham die beloftes toegesê en aan sy saad. Hy sê nie: En aan die sade, asof dit op baie sien nie, maar op een : En aan jou saad, dit is Christus". 
Ons kan dus stel dat 'n mens verskillende tipes eksegese in die Bybel kry. Vraag is of dit so is dat omdat hulle in die Bybel is, hulle standaard is en geen ander manier gebruik kan word nie. Of is dit dalk so dat omdat daar verskillendes is, die Bybel nie 'n standaard eksegese wil gee nie?

Nadat die probleemveld nou kortliks vasgestel is, kan ons nou enkele van hierdie probleme behandel.

\section{Die Perspicuitas van die Skrif.}

Die duidelikheid van die Skrif wat die Reformasie teenoor Rome geponeer het, het tot vandag toe 'n teologiese twispunt gebly waar die twee lynreg teenoor mekaar staan. „Beide gaan daarvan uit dat die Heilige Gees as ,auctor primarius" ook die ware uitlegger van die Skrif is. Hieraan verbind Rome egter die tese dat die Skrif duister is en moeilik verstaanbaar is, dat alleen die onfeilbare leergesag van die kerk hierdie uitlegging van die Gees met afdoende sekerheid kan gee: Die Reformasie aan die anderkant leer dat die verligting van die Heilige Gees dit vir elke gelowige moontlik maak om die eie bedoeling van die Skrif te verstaan omdat dit vir die geloof eenvoudig en helder is". ${ }^{6}$ ).

Uit die wyse waarop die oudste Reformatoriese teoloë die perspicuitas van die Skrif ontwikkel het, blyk duidelik dat hierdie duidelikheid nie onbeperk opgevat word nie, maar betrek word op die leer van die saligheid waartoe die mens geloof nodig het. Die duidelikheid van die Skrif kan nooit los van die geloof gesien word nie. Wie nie glo nie, sal van die heilswaarheid van die Bybel niks verstaan nie. Want die Skrif wil ons altyd leer om God te ken (Calvyn) of Christus verkondig (Luther). In wese is dit dieselfde want volgens Calvyn is waaragtige Godskennis alleen in Jesus Christus moontlik. Die Reformatore wil dat die vertolking van die Skrif Christusverkondiging moet wees.

Daarom beteken die perspicuitas van die Skrif, volgens Reformatoriese besef, allermins dat alles in die Skrif helder en eenvoudig is, sodat elkeen dit wat hy lees onmiddellik kan verstaan, of dat daar geen verborgenhede van God voorkom wat die begrip van die mense te bowe gaan nie, of dat daar duistere plekke sou wees wat grondige studie sou verg nie.

Daarom is 'n volstrekte duidelikheid van die Skrif in empiries-faktiese sin, los van die faktor van die Gees, geen Re-

a) R. Bijlsma, Schriftgezag en Schriftgebruik; Nijkerk MCMLXIV, bls. 147 
formatoriese leerstuk nie. Die noodsaak van die bestudering en vertolking van die Bybel is deur die Reformatore altyd op die voorgrond gestel. Hierdie vertolking van die Skrif is belangrik omdat ook hierin die heilsboodskap weerklink.

In die perspicuitas gaan dit daarom dat die moeilikhede en duisterheid wat eie aan die Skrif is, nie met behulp van 'n gesag buite die Skrif om benader moet word nie, maar alleen vanuit die Skrif self. Die Skrif moet altyd met die Skrif verklaar word. 'n Hermeneutiek van die Bybel sal dus daarvan moet uitgaan dat die Skrif volgens sy eie bedoeling vertolk moet word.

Dit het egter nie die bedoeling om menslike interpretasie uit te skakel nie.

„Die aandag van die Reformatore vir die Heilige Skrif weerspreek dit ten ene male. Luther het meermale op die groot betekenis van die kennis van tale vir die suiwere verstaan van die Skrif gewys. 'n Mens kan sê dat juis die ,sui ipsius interpres" lei tot 'n besig wees met die sin van die Skrif self, met sy vertolking, waarin dan die Skrif self as interpres 'n beslissende rol speel". ').

Vertolking van die Skrif is nodig en noodsaaklik en volg?ns Reformatoriese insig moet dit altyd Christusverkondiging wees. Die Heilige Skrif moet verklaar word om na Sy wesenlike en diepe $\sin$ en ryke inhoud gesien en verstaan te word (Luk. 24:32 Emmausgangers) (Hand. 8:26 Kamerling van Ethiopieë).

Onthou die taal van die Bybel se tyd is dikwels nie ons taal nie, die wêreldbeeld van toe is dikwels nie ons wêreldbeeld nie. Daarom beteken die perspicuitas van die Skrif nie dat die Skrif geen uitleg nodig het nie, maar eerder dat die Skrif na moeisame arbeid die Skrif self moet verklaar.

\section{Die verhouding van die Ou Testament en die Nuwe Testament.}

„Ons vat die Heilige Skrif saam in twee boekdele, dié van die Ou en dié van die Nuwe Testament". ").

Die erkenning van die Heilige Skrif het betrekking op die Ou en Nuwe Testament. „Die Ou Testament staan nie in die Bybel as hoogtepunt van 'n voor-Christelike religie nie. Die Ou Testament staan in die Bybel omdat God (en nie mense nie)

i) R. Bijlsma, a.w., bls. 152 .

s) Ned. Gelofsbelydenis artikel IV. 
dit so wil omdat die Nuwe sig op die Oue beroep"."). 'n Mens kan ook telkens die een sonder die ander nie reg verstaan nie.

Dit was egter nie altyd so vanselfsprekend dat die $\mathrm{Ou}$ en Nuwe Testament op gelyke vlak naas mekaar gehandhaaf moes word nie.

In die 2de eeu byvoorbeeld het Marcion die geldigheid van die Ou Testament in twyfel getrek. Hy skryf die Ou Testament aan 'n demiurg toe en reken dat die God van die Ou Testament 'n bose oorlogsgod is.

In die tyd van die Reformasie het hierdie dwaling, veral in Doperse kringe, herleef. Vir hulle was die Ou Testament 'n boek van ,die dooie letter van knegskap en uitwendige heiligheid". ${ }^{10}$ ) Dit staan agter by die leer van Christus en moet daarom na die koms van Christus verdwyn.

Hierdie minagting van die Ou Testament is sterk deur die Reformatore bestry. Vir hulle is Ou en Nuwe Testament twee bedelinge van dieselfde genadeverbond. Die Ou Testament bly van krag omdat die Nuwe Testament telkens na die Ou Testament verwys as die betroubare ,graphe." Ook Christus en die apostels aanvaar die Ou Testament ten volle (Luk. 16:29, Luk. 24:27, Joh. 5:46, Hand. 24:14). Christus stel dat die Skrifte van Hom getuig. En in Sy woord aan die Emmausgangers lê Hy die Ou Testament uit, beginnende by Moses en al die profete, t.o.v. ,wat in al die Skrifte op Hom betrekking het. Hierdie Skrifbeginsel van die Reformasie bring mee dat in die Reformatoriese Teologie die verhouding van Ou en Nuwe Testament altyd met nadruk aan die orde kom. Daarby word dan altyd teruggegryp na die uitspraak van Augustinus dat die Nuwe Testament reeds op verborge wyse in die Ou Testament aanwesig is, en dat die Ou Testament pas duidelik word uit die Nuwe" ${ }^{11}$ ).

Luther en Calvyn het met nadruk aan die eenheid van die Heilige Skrif vasgehou. Die eenheid van die Skrif is in Christus veranker. Jesus Christus is die doel van die ganse Skrif en die substansie van die evangelie.

Luther is van mening dat die Skrif self die sleutel gee om sig te verstaan. Die sleutel is die verkondiging van Jesus Christus. Hy is die middelpunt van die ganse Skrif. So kom Luther

9) Dr. .J. Koonmans - Die Nederlandse Geloofsbelijdenis. 3de Druk, Amsterdam, bls. 33 .

10) A. D. Polman. Onze Nederlandsche Geloofsbelijdenis. T. Wever, Franeker. 1ste deel, bls. 189.

11) R. Bijlsma, aw., bls. 189. 
dan ook tot die bekende uitspraak dat die Skrif die krib is waarin Christus lê. Hiermee het Luther nie 'n resep gegee om alle moeilikhede in die uitleg van die Skrif op te los nie. Want Christus is tegelyk meer as die Skrif. Hy is die Heer van die Skrif. En Hy gaan alle menslike begrippe te bowe. Deur die eenheid van die Skrif uitsluitend in Christus te bely, het Luther 'n grondreël opgestel wat enersyds die versnippering van die Bybel afwys en andersyds waarsku teen 'n goedkoop en lynregte Bybelgebruik.

Calvyn spreek „enersyds oor die ooreenkoms tussen die Ou Testament en die Nuwe. Dan gebruik hy die woord ,gelykheid" (Similitudo). Andersyds meet hy die verskil tussen beide Testamente breed uit. Maar hy praat dan nie van ,ongelykheid" (Dissimilitudo), wat by 'n antitetiese gedagtegang voor die hand sou lê nie, maar van "verskeidenheid" (differentia). Die verskille sien hy op die agtergrond van die eenheid. Hulle verbreek nie die eenheid nie, hoe groot hulle ookal mag wees. Die belofte is dieselfde en die fondament van die belofte bly ewe-eens dieselfde, naamlik Christus. Die verskille batref alleen die vorm en inkleding, die aard van die bedeling, waarin die dinge plaasvind (modus administrationus) maar nie die dinge self nie (substantia)". ${ }^{12}$ ).

Hierdie uitgangspunt sou onaangetas bly ook as in die 17de eeu die tekskritiek 'n blywende plek verower en in die agtiende eeu die histories-kritiese ondersoek van die Skrif langsaam maar seker veld wen. Die groot nadruk wat op die eie kakakter van die Ou Testament gelê word, beteken geensins dat die gesag van die Bybel aangetas word nie.

By die maniere van ondersoek van die Skrif was in 'n sekere $\sin$ 'n proses aan die gang wat weer tot 'n uitmekaar ruk van beide Testament sou lei.

"Onder invloed van die deīsme, wat 'n natuurlike en historiese sienswyse bevorder, word die Ou Testament steeds meer beskou as 'n kinderlike periode in die kultuurgeskiedenis van die mensheid. Op hierdie wyse kon dit enersyds met behulp van die begrip van die goddelike pedagogie, as voorbereiding vir die volle rypheid van die Christendom nog positief gewaardeer word, maar andersyds is die deur geopen vir die negatiewe opvatting, dat die

12) R. Bijlsma, a.w., bls. 199. 
Ou Testament 'n laere vorm van godsdienstigheid verteenwoordig". ${ }^{13}$ )

Die bodem was voorberei vir 'n moderne „marcionisme" wat sy vertolking vind in die bekende stelling van von Harnack „Om die Ou Testament in die tweede eeu te verwerp was 'n fout wat die kerk tereg afgewys het, om dit in die sestiende eeu te behou, was 'n lot waaraan die Reformasie sig nie kon onttrek nie, om dit egter sinds die negentiende eeu in die Protestantisme nog as kanoniek in stand te hou, is die gevolg van kerklike en religieuse onmag". ${ }^{14}$ ).

Dit het die kerk gedwing om opnuut weer te besin oor die betekenis van die Ou Testament en die verhouding van die beide dele van die Heilige Skrif.

Vir die kerk van die Reformasie is en bly Ou en Nuwe Testament saam die Heilige Skrif ,wat die wil van God volkomelik bevat en word alles wat die mens moet glo om gered te word daarin genoegsaam geleer". ${ }^{15}$ ) Beide leer dieselfde Drie-enige God, dieselfde leer van saligheid, en dieselfde wandel in dankbaarheid.

Die Ou Testament is van begin tot einde profetiese heenwysing na die beloofde Christus wat gekom het. Dit gaan altyd weer om die Skrifte van die Ou en die Nuwe Testament as instrument in die hand van die Gees, omdat die Heilige Gees die geloof werk deur middel van die uit die Bybel geputte woord van die verkondiging. En in die geloof kry ons te doen met die persoon en werk van Jesus Christus. Die uit die Bybel geputte woord van die verkondiging sal dus altyd Christus-verkondiging moet wees. Want dit is ook die bedoeling van sowel Ou as Nuwe Testament, om Christus te verkondig. Hulle verhouding is een van "vroeëre" en "latere" in die mededeling van die openbaring en hulle kan alleen in onderlinge samehang verstaan word. Daar kan nie een wegval nie, want dan word daar skade gedoen aan die gehele beeld.

In die voortgang van die werk van God moet die $\mathrm{Ou}$ Testament in sy geheel en met al sy dele naas die Nuwe Testament en die Nuwe naas die Oue, gesien word as

13) R. Bijlsma, a.w., bls. 190.

i1) A. D. R. Polman, a.w., bls. 202.

${ }^{15}$ ) Ned. Geloofsbelyydenis - art VII. 
mekaar se aanvulling in die vervulling. Beide neem hulle getuiende plek rondom Jesus Christus in.

„Deur die evangelie van Jesus Christus weet ons dat die geskiedenis van Israel die geskiedenis is van Gods volk op hierdie aarde; dat die wet op Christus, wat dit vervul het, sien, dat die diens in die tempel aanduiding is van die offer op Golgota, en dat die profete van Christus gespreek het. Tussen die $\mathrm{Ou}$ en Nuwe Testament lê die koms van Christus van wie beide getuig, die Ou Testament profeties, die Nuwe apostolies. Daarom behoort by alle verskille, wat nie vergeet mag word nie, Ou en Nuwe Testament onlosmaaklik byeen". ${ }^{16}$ ) Calvyn sê hulle is twee bedelinge van dieselfde genadeverbond. En E. Brunner poneer dat beide Ou en Nuwe Testament die volle woord van God is, onderskeie in bedeling, maar een in leer.

Ook by die Heidelbergse Kategismus (Sondag VI) waar gesê word dat ons Christus ken ,uit die heilige evangelie wat God self eers in die paradys geopenbaar het en daarna deur die heilige aartsvaders en profete laat verkondig en deur die offerandes en ander seremonies van die wet vantevore laat afbeeld het, en uiteindelik deur Sy eniggebore Seun vervul het", word die ,eenheid van die Heilige Skrif as getuienis van Jesus Christus en die historiese gang van die evangelie van die paradys af tot by die vervulling duidelik na vore gebring". ${ }^{17}$ ).

Dit is een maatstaf wat kan en moet aangelê word om die geldigheid van elke uitleg van die Skrif te toets, naamlik of Christus gestel word in die middelpunt van die getuienis.

Om die verhouding van die Ou en die Nuwe Testament heeltemal reg te sien, sal daar gelet moet word op die Skrifgebruik in die Bybel self en dan veral hoe die Nuwe Testament die Ou Testament aanvaar en uitlê.

Want die wese van die Hermeneutiek, naamlik om wat geskrywe staan oor te bring in eie tyd en omstandighede, ontmoet ons reeds in die Bybel self. Dit lê dus voor die hand om uit die wyse waarop die Bybelskrywers dit doen, enige riglyne vir onsself te vind.

16) D. J. Koopmans, a.w.. bls. 33.

1i) J. P. Oberholzer, Christusverkondiging in die Ou Testament. Art. in die Herv. Teol. Studies, 19de Jaargang, afl. I en II, Oktober 1963, bl. 2 . 
Reeds in die Ou Testament vind ons 'n sekere manier van Skrifgebruik. Maar dit geld in besonder die gebruik van die Ou Testament in die Nuwe. 'n Reformatoriese Teologie wat daarvan uitgaan dat die Skrif homself moet verklaar, sal homself moet afvra hoe in die Bybel self die Bybel gebruik word en dan veral hoe die Ou Testament uitgelê en toegepas word in die Nuwe. Want 'n Skriftuurlike Teologie sal sy Skriftuurlike karakter altyd moet toon in die Skriftuurlike wyse van sy Bybelverklaring. 